\title{
WILL MARINA ABRAMOVIĆ DIE?
}

\author{
A B S S T R A C
}

The gradual and then ecstatic acceleration and diversification of Marina Abramović's choices in life and art are the result of her commitment to install and introduce into her performancemachine the power of perpetual mobility. That final line of end/ ings of the horizon disappearing into Nothingness, the line of Death which she touched and invoked in her life and work on many occasions, is neither to be melancholically accepted, nor desperately tamed or fiercely denied. Abramović activates this line of the last horizon, turning it around so that it becomes vital rather than fatal, cyclic rather than liminal, (re)turning - aspace that gives birth to (hyper)productivity. There is a relentless striving to disturb, slow down, curb, disable the work of Time, to change the path of Time's arrow. She endeavours to reconstruct, revitalise, rejuvenate, to extend the duration of the body of her art, the body of performance art and, consequently, of her biological body. A number of methods and mechanisms are used for this purpose - starting from documentation, technical multiplication, substitution, extension and virtualisation and even spectacularisation of her body and the body of her art.

\section{Svetlana Racanović}


Michel Foucault thought that sexuality had been "invented" in the nineteenth century, when Christian confession pooled around and into a comprehensive scientific study of the phenomenon of sexuality, and when sexuality became the subject of a substantial body of research and knowledge, as well as a meta-strategy of (bio-political) power, of dominion over life. Jean Baudrillard, on the other hand, argued that death had been "born" in the sixteenth century, when "it has lost its scythe and its clock, it has lost the Apocalyptic Horsemen and the grotesque and macabre plays of the Middle Ages"1, that is, when death became psychologically internalised and transformed into the fear of death. For sure, people lived and died even before the nineteenth or the sixteenth century, but it is starting from these points in time that life began to be considered, defined, (re)appraised in relation to sexuality and death - life itself became a discourse. However, the more we define our lives and our bodies as discursive creations or social (or artistic) constructs, and the more we invest in the body as a project, the more disturbing and unacceptable the certainty of its disappearance, that is, of death, becomes. Western practices of denying or sublimating Thanatos through subordination of nature, and the production and accumulation of worth (goods) by the productive, constructive Eros, nonetheless end in the triumph of death: "Eros is nothing but an immense detour taken by culture towards death." ${ }^{22}$ Despite the undeniable technical/technological advancements and the development of many methods and techniques of body reconstruction, death remains a biological inevitability, the zero point in which the power to control one's own body or existence ceases. As something unknowable, out of our control, death radically undermines all that we consider important or real, destabilising the world governed by logic of possession, acquisition, accumulation, preservation. It is "fatally dangerous" to the concept of the self-made man, to his prospects of world building, and to the reliability of his production of value and meaning. As Zygmunt Bauman writes, modern obsession with the body is an attempt to deny its ultimate boundary (death) by successfully overcoming the individual boundaries that we face in single points in time. ${ }^{3}$ Culture as a whole is considered an operation of multiple forms, a strategy to "re-shape death": to alleviate the horror that emerges from death as "absolute alterity", to restrain, retaliate or peacefully accept, to reconcile with death in order to give meaning to life. Life is possible in spite of, or precisely because of the perception of the inevitability of death. According to Bauman, fear of death, or the "ultimate fear", is "a natural resource that can boast infinite supplies and complete renewability". ${ }^{4}$ Repetition of the acts and the effects of the living body functions as a steady stream of new beginnings, of "re-birth" that delay and deny death, while, at the same time, re-confirming and questioning it once again. 
Marina Abramović has experimented with different methods of delaying and even "denouncing" the death of her body, and of the body of her art. This body has continually and radically tested and moved against its own psycho-physical boundaries, breaking (through) thresholds of pain, challenging the very limits of life. It then practised various techniques of self-care - a series of physical and meditative practices that helped conquer the domains of calmness, mind relaxation, and superior consciousness. In addition, Abramović "packed" these practices together into a Cleaning the House programme, which later became the so-called Marina Abramovic Method, intended for others as a special educational-therapeutic and artistic programme. Abramović often reminds that - especially before or after demanding art projects - she resorts to retreats as escapes from civilisation into spaces of seclusion and devotion, which provide special care and nurturing to body and spirit. However, this is also a body (of the artist, of performance art) that is ephemeral, aging, leaning towards its mortality and disappearance. It therefore needs more than just Cleaning the House and Cleaning the Mirror programmes as revitalising acts that remove the fear of death; it also needs to adapt to the context of contemporary models of living. These models continuously encourage activities and signs of rejuvenation, of keeping in shape, and treat the body as a project, an option, as material subject to reconstruction, transformation, revitalisation, correction, upgrading. These models not only delay, or deny death, but relate to it almost as to an unnatural phenomenon.

Marina Abramović has done manifold updates of this inherent programme of perpetuation, continuation, cleansing and rejuvenation, of the renewal of her body and her art. At first, she did so by resorting to visual media (photographs, videos) that fixed the moments of the performances' liveness, gaining victory over the ephemerality of the performer's/performance's body. This, therefore, resulted in the possibility to repeat the act and simulate the continuity of its duration, even for eternity. She then engaged in the practices of documenting, committing to memory, preservation and re-enactment (restoration of the past as Other, difference, new); then through the practice of institution building (the body of an institution as the "second body" of the artist/art, or as the permanent, eternal body of the art/artist, which is ephemeral); through pedagogical activities of the artist, through her engagement, since 1991, as a performance art teacher ("When you arrive at a certain age, you should unconditionally share your experience with generations of young artists and they can share with you their feeling of the present moment" ${ }^{\prime)}$; through maintaining that body (of the artist, of art) remarkably "fit" by always keeping it present in the networks of the modern media and cultural industries (and fame is, according to Zygmunt Bauman, "a shorthand for being kept in the memory of posterity"7). According 
to Joseph Roach, celebrities have two bodies, just like kings - a natural body that deteriorates and dies, and a cinematic one that is immune to that. However, Roach continues, although this immortal body in the image (of the image) is preserved on film, in a digital file or in the memory of the audience as an afterimage, it always carries a disturbing reminder of its "original".

The body of Marina Abramović and the body of her art, strive to preserve what they had gained, to maintain the "high tone" of those natural powers they had been growing, activating, strengthening since the 1970s. At the same time, they strive to plug these powers into contemporaneity, by a careful design of appearances and representation, and by nurturing an impression of constant presence and preservation of the body, and its resistance to time. Finally, after some of her works had been virtualised and reinterpreted as synthetic performances in the world of Second Life (Imponderabilia, 2007) and video games (Artist is Present, 2011), the artist "made her claim on eternity" thanks to the world of virtual reality. In the art platform Acute Art (2017), the artists (Marina Abramović, Jeff Koons, Ola fur Eliasson) create a VR gallery meant to explore and encourage the transition of art from the physical world to the new reality of contemporary technologies. ${ }^{9}$ By recreating her living body through an electronic twin, an avatar, Abramović leads the viewers towards the growth of their (ecological) consciousness. Moreover, by using the latest technologies to multiply and virtualise her physical body, the artist completes or continues in un-expected ways her primary artistic mission of permanently developing the powers of the body - its upgrading, "exterritorialisation", extension through new means, media and instruments - consequently redefining the position of the living body of the performer and the very nature of performance art itself.

Therefore, the continuous renewal and enhancement of the power of her psycho-physical body and levels of awareness through special regimes or physical practices that fall into the domain of most extreme and sophisticated technologies of the self, or of self-care, have naturally and desirably contributed to the revitalisation of the "body" of her art, the art of the "living body", of performance, all in a heartfelt desire to ensure duration and longevity to both herself and the body of her art. In time (starting from the '90s), these practices were complemented with contemporary methods of rejuvenation, reconstruction of the artist's body, redesign of its appearance, its virtualisation and multiplication by its projections into the system of mass media; through mechanisms of the (un-wanted) institution of the artist as an art celebrity. At the same time, these mechanisms were naturally accompanied by practices of "rejuvenation" and preservation of the body of Abramović's art. This was done not only by means of comprehensive documentation and commitment to 
memory, but also by actualisation, re-enactment of her past works and mediatic translation of her art, i.e. its performance and distribution for or through the electronic media, and therefore, by virtualisation and multiplication of her art's body. However, these later techniques of spatial and temporal extension of the appearances more than of the actual presence of her body and the body of her art, do not indicate a loss of power that this body/bodies have accumulated through the years. They are now marketed and launched in a modern, mass-friendly packaging, which, to a certain extent, revises, modifies and redefines the old dichotomy between outer and inner, between form and essence. In addition, the dictum (or perhaps, the phantasm) that was so closely tied to the ontology of performance art itself, i.e. that its ephemerality gave it also the power to resist to any attempt of repetition, preservation and commodification - this perceived immunity to its being co-opted by the capitalist machine - became inevitably and willingly sacrificed on the altar of the contemporary art system, so firmly entangled in the nets of capitalist spectacle.

In the documentary film The Space in Between: Marina Abramović and Brazil (2016), the artist recorded her trip to Brazil during which she witnessed, and sometimes directly participated in healing rituals of various Brazilian shamans, combining these documented fragments with episodes of her performances done in the majestic Brazilian landscapes characterised by waterfalls, caves, forests and hills. This full bodily "immersion" in the setting of pure nature, or in the rituals of true shamans that govern natural forces, was supposed to "renew" the energy, the natural quality of her and her art's body, to revitalise the powers that these bodies had acquired in "direct contact" with "pure" nature (while the film medium was meant to provide the artist with an extended duration, the power of dissemination in time and space). However, the performative presence of the artist is manifested here more like a posture than an actual adaptation. It reads as an appearance that has been carefully designed, a directed stage-act within an intact environment, much more than as a natural correspondence or belonging to the context, or as sharing in its true nature. Namely, authentic healing rituals that border on the miraculous and settings of pure nature that induce exaltation are no longer, or not just the habitat of her art, but have (also) become a mise-en-scène of temporary escape, a retreat for the contemporary Westerner, a space in which he/she can temporarily experience difference, and within which the artist can re-apply her well-tried styling, her already co(mmo) dified mediatic and artistic appearance. Abramović, who has already had a long and fruitful experience of such retreats, and who continues to advocate her previous mission - to raise the level of people's awareness through art - now diversifies and modernises (virtualises, popularises, globalises) the strategies that she believes may serve that mission. Still, it might be possible to view this 
project in a Hal-Fosterian sense, i.e. as those "pseudo-ethnographic reports in art that are, in fact, disguised travelogues from the world art market or as the new form of flânerie". ${ }^{10}$

The artist also meticulously staged her own funeral ("The funeral is the artist's last art piece before leaving" "11), designing in detail this future ceremony, planning for the presence of three coffins ${ }^{12}$ containing her three bodies, of which, of course, only one would be real, and having them buried in the three cities for which her most important personal and professional moments are tied (Belgrade, Amsterdam, New York). The artist also demanded that the final destination of her real body, of her actual mortal remains, was kept undisclosed to the public. This projection into the future event reveals the wish of the artist to be present, permanently or indefinitely, even when her living body is no longer; to install her mortal body/bodies as a sort of memorabilia; as monuments that mark and perpetuate her participation in the creation of the (cultural) history of the three cities, as well as of the history of performance art, which would include the funeral of the performance artist herself. The reproduction of the dead body is not a naive attempt to outsmart death, but rather the final gag, one last ironic pirouette of the performance artist and her art seen as the ephemeral art of the body or the art of an ephemeral body. Namely, this concept seems to allow for the impossible: it is as if the living body, the cardinal instrument of performance art, had acquired such "fantastic" powers that it could multiply even in death. And consequently, this presentation of "excessive evidence", i.e. the impossibility to differentiate between true and false evidence on the death of the body, almost causes doubt in its very mortality.

Writing about Damien Hirst, Jerry Saltz refers to the situation in Ridley Scott's Blade Runner, in which an advanced replicant, the almost humanoid Roy meets the scientist who created him, i.e. made him, with a very "human" question on his mind: why was life given to him if has to be taken away. Somewhat perplexed, the scientist asks back "What seems to be the problem, Roy?" "Death seems to be the problem! I want more life ... fucker!", Roy answers. And, as Saltz concludes, Hirst's work is all about "more life". Likewise, Marina Abramović's work is constantly seeking, inventing and exploiting all kinds of techniques and methods for prolonging her life or the life of her art. It is a passionate quest for the power of self-preservation, self-renewal, and the continuous revitalisation of performance at all costs; even at the cost of its comprehensive memorialisation, multiplication, virtualisation, spectacularisation, and even commodification and commercialisation by its inclusion in the highly-operative mechanism of the global capitalist cultural industry. 
Zygmunt Bauman, in: Chris Schilling, The Body and Social Theory (London: Sage Publications, 2003), 7.

The MAI (Marina Abramović Institute) in Hudson was conceived as a kind of artist's legacy, as a multidisciplinary center of $33,000 \mathrm{~m}^{2}$ intended for "supporting, exploring and presenting performance art", as a cooperation platform between different arts, sciences and humanities and a place for practicing The Abramović Method (https://mai.art/about-mai). In November 2017, the artist officially canceled the project, of estimated worth of 31 million dollars. According to the artist, however, the lack of physical space or the seat of the institute does not mean its disappearance, since the institute will realize and host its programs in other spaces. Adapting to the new situation, the artist also devised a new slogan: "Don't come to us; we come to you". It could also be said that it was an "act of providence" that this institute, intended for performances an immaterial art, remained immaterial itself.

"Personal Views on the Past, Present and Future of Performance Art,"YouTube video, 32:28, posted by Harvard GSD, November 18, 2011, https://www.youtube.com/watch?v=b8za92MIKhM. Joseph Roach, It (Ann Arbor: University of Michigan Press, 2007), 36.

Anna Cafolla, "Marina Abramović \& Jeff Koons front new online VR gallery", Dazzed, November $21, \quad 2017, \quad$ http://www.dazeddigital.com/artsandculture/article/36302/1/marinaabramovic-jeffkoons-front-frst-online-vr-gallery.

Hal Foster, The Return of the Real: The Avant-Garde at The end of the Century (Cambridge: MIT Press, 1996), 180.

An Artist's Life Manifesto: Marina Abramović, in: Hans Ulrich Obrist, Marina Abramović: Conversation Series 23 (Cologne: Verlag Der Buchhandlung Walther Konig, 2010), 89.

The opera When Marina Abramović Dies (2011), directed by Bob Wilson and premiered at the Manchester International Festival 2011, starts with three coffins on the stage. 
Baudrillard, Jean. Symbolic Exchange and Death. London: Sage, 1993.

Bauman, Zygmunt. Liquid Fear. Cambridge: Polity Press, 2006.

Cafolla, Anna."Marina Abramović \& Jeff Koons front new online VR gallery." Dazzed, November 21, 2017. http://www.dazeddigital.com/artsandculture/article/36302/1/marinaabramovic-jeffkoons-front-frst-online-vr-gallery.

Foster, Hal. The Return of the Real: The Avant-Garde at The end of the Century. Cambridge: MIT Press, 1996.

Obrist, Hans Ulrich. Marina Abramović: Conversation Series 23. Cologne: Verlag Der Buchhandlung Walther Konig, 2010.

"Personal Views on the Past, Present and Future of Performance Art."You Tube video, 32:28. Posted by Harvard GSD. November 18, 2011. https://www.youtube.com/watch?v=b8za92MIKhM.

Roach, Joseph. It. Ann Arbor: University of Michigan Press, 2007.

Schilling, Chris. The Body and Social Theory. London: Sage Publications, 2003. 


\section{DA LI ĆE UMRETI MARINA ABRAMOVIĆ?}

\section{Svetlana Racanović}

Postupno, a zatim žestoko ubrzanje i diversifikovanje životnih i umetničkih izbora i angažmana reflektuje želju umetnice Marine Abramović da se u njenu performans mašinu usadi i stavi u pogon sila perpetumobilnosti. Toliko puta u njenom životu i radu opipavana i izazivana linija kraja, okončanja, nemanja-posle-toga, dakle, smrti, time se ne bi melanholično potvrđivala ali ni očajnički poricala niti divlje zauzdalavala, već bi se ta linija poslednjeg horizonta snažno zarotirala i umesto fatalne postala vitalna, umesto granične postala ciklična, ona koja (se) vraća, ona iz koje se biva (hiper)produktivnim. Različitim strategijama i praksama ona pokušava da zakrivi strelu vremena, da zakoči, uspori, poremeti, sabotira njegovu logiku. Ona želi da rekonstruiše, revitalizuje, podmladi, produži trajanje tela svoje umetnosti, tela umetnosti performansa i, konsekventno, sopstvenog biološkog tela posežući za različitim metodama i mehanizmima supstituisanja, tehničke multiplikacije, ekstenziranja, virtualizacije, pa i spektakularizacije sopstvenog tela i tela svoje umetnosti.

KLJUČNE REČI: MARINA ABRAMOVIĆ, PERFORMANS, EFEMERNOST, SMRT, PODMLAĐIVANJE TELA UMETNOSTI/ UMETNIKA, TRAJNOST

\section{OD ESTETSKOG KA ETIČKOM:}

\section{MIT I METAFORA KAO MODUS NARATIVA KOD LEVINASA Kristina Bojanović}

U ovom radu pokušaću da pokažem da Levinasova etika sadrži estetiku mitološke naracije koja ima metaforično ("kao da" značenje) i arhetipsku dimenziju, dok ću odnos između etike i estetike nastojati da objasnim posredstvom Levinasovog poimanja erosa. Ovi ciljevi zasnovani su na pretpostavci da mit predstavlja uroboričku osnovu Levinasove filozofije kojom je on uspeo da se otrgne iz egologije zapadne misli, ali i iz iskustva vlastite imaginacije. Mit govori o univerzalijama posredstvom različitih predstava, odnosa, likova itd. Imajući u vidu da su univerzalije arhetipovi, i da svi arhetipovi u istoriji čovečanstva imaju estetsku dimenziju, Levinasova filozofija "nudi" arhetipske strukture mitova kroz operativne pojmove poput erosa, beskonačnosti, ženskog, traume, materinstva, plodnosti... Pokušaću da pokažem da je Levinasovo uspostavljanje etike kao prve filozofije zasnovano na jeziku metafora kao gradivnog i nesaznatljivog temelja psihe.

KLJUČNE REČI: MIT, METAFORA, EROS, ETIKA, ESTETIKA, DRUGO, ŽENSKO

\section{AISTHETON (ČULNO OPAŽANJE) U VREME DRUŠTVENO-POLITIČKE KRIZE Nebojša Vilić}

Glavna namera ovog rada je da predloži način razumevanja odnosa između estetike i politike u misli Žaka Rensijea kao teorijskog instrumenta za primenu u konkretnoj situaciji protesta. Nadalje, protest će se uzimati samo kao društveni događaj uživo, ali i kao telesno iskustvo sa posledicama i rezultatima koji proizlaze iz toga. Polazeći od Rancijerovog stanovišta raspodele čulnog i načina na koji predmet bez glasa mora da dostigne svoje pravo na govor, ovaj rad se bavi nekolicinom tema prema kojima se može zaključiti da samo fizičko prisustvo tokom protesta daje mogućnost subjektu da taj čin oseti razumno. Ovo je prilično različit pristup telesnog razumevanju sveta i iskustava poznatih kao odnos umetnosti i estetike, označavajući aistheton i kao istovremenog nosioca značenja političkog. Studija slučaja korišćena za ovu primenu je takozvana Obojena revolucija, i „bojenje“ makedonske kapije u Skoplju, u Makedoniji.

KLJUČNE REČI: AISTHETON, KOLEKTIV, TELESNOST, REŽIM DOŽIVLJAJA, NEMI GOVOR, POLITIKA, PROTEST, RAZUMAN 